\title{
Probabilistic Projections of Annual Runoff and Potential Hydropower Production in Finland
}

\author{
Elena Shevnina ${ }^{1, *}$, Andrey Silaev ${ }^{2}$, Timo Vihma ${ }^{1}$ \\ ${ }^{1}$ Finnish Meteorological Institute, Finland \\ ${ }^{2}$ National Research University Higher School of Economics, Russia
}

Copyright $(2019$ by authors, all rights reserved. Authors agree that this article remains permanently open access under the terms of the Creative Commons Attribution License 4.0 International License

\begin{abstract}
Exceedance probability of a potential hydropower production was evaluated for 12 river basins located in Finland. The exceedance probability curves of the potential hydropower production were assessed from the probabilistic projections of annual runoff rate. The exceedance probability curves of the ARR are constructed within the Pearson type 3 distributions from simulated parameters, i.e. mean values, coefficient of variation and coefficient of skewness. In our case study, these parameters were simulated from the mean values of annual precipitation rate calculated from outputs of two climate models under three Representative Concentration Pathway's climate scenarios. The future changes in the potential hydropower production for the selected river basins were evaluated on the assumption that a potential hydropower production is linearly related to ARR in all range of exceedance probabilities.
\end{abstract}

Keywords Climate Change, Water Resources, Annual Runoff Rate, Potential Hydropower Production, Probabilistic Hydrological Projection

\section{Introduction}

Water has a long history of being one of a key natural resource in energy production. Nowadays water managers use deterministic and probabilistic hydrological forecasts on a stream flow runoff to optimize rules of water regulation, distribution and energy production, and to prevent losses due to water runoff extremes [1, 2, 3]. Risks in hydropower production are connected to surface runoff events of rare occurrence-floods lead to energy spills, and water shortages cause interruptions on hydropower generation. Thus, national hydro-meteorological services need to provide a probabilistic form for surface runoff forecasts to estimate hydropower production on seasonal and long-term scales $[2,4$, 5].

Probability density function is a natural form to describe a random variable. In hydrology, an exceedance probability curve is better known by water engineers $[6,7$, 8]; it is the inverse of the probability density cumulative. The exceedance probability indicates likelihood that a particular runoff value will be exceeded. Probabilistic hydrological projections give the values of river runoff together with their exceedance probability; thus they allow a better understanding of the future risks of hydropower generation.

Long-term hydrological forecasts gained in importance under changing climate. A concept of climate is suggested based on the random nature of climate variables by Monin [9]. In this concept, the climate is described by statistical estimators, i.e., mean value and variability, evaluated from the observed time series of precipitation, air temperature, evapotranspiration, river runoff, etc. for a period of 20-30 years. This climate concept relies on a "stationary" assumption, without taking into account any changes in the future. Nowadays, the stationary assumption is unsuitable due to the trends detected in the time series of the observed meteorological variables [10]. Rosmann et al. [11] revised river runoff time series observed globally. The authors conclude that the highest numbers of statistically significant trends are detected in the time series of an annual runoff.

The trends in climate variables are particularly pronounced in the Arctic [12]. The observed precipitation time series suggest an increase by $15-20 \%$ over recent decades in the northern circumpolar region [13, 14, 15]. This affects water resources available for hydropower generation, which is a key of an energy market in the Nordic countries [16]. This study focused on the annual surface river runoff, as defined in [17]. The long-term probabilistic projections of annual runoff were evaluated, which means that the runoff values were evaluated along with their exceedance probability.

Many studies concerned with the impact of climate change on the vulnerability of hydropower production [18, $19,20,21,22]$ apply various physically-based hydrological models for the simulations of the future 
water resources under various climate projections. In the physically based hydrological models, the runoff time series are simulated based on the rainfall time series provided by global or regional climate models from a single projection or an ensemble of climate projections. The simulated time series are analyzed using the methods of frequency analysis [8]. Many studies are usually limited by the estimation of the mean values of annual runoff, which is further applied to evaluate energy production indexes such as the annual mean usable capacity of a current hydropower network [22] or potential hydropower production $[18,21]$. The knowledge of the mean annual runoff however does not allow to assess the changes in the runoff of rare occurrence, evaluation of which is important for a sustainable water management [24, 25].

In our study, a modelling approach based on the Fokker-Planck-Kolmogorov equation adapted for hydrological applications was used for the evaluation of the annual runoff along with its exceedance probability $[26,27,28,29]$. We applied the method of Advance of Frequency Analysis method suggested in [26]. It relies on a "quasi-stationary" climate concept, based on the consideration of two time periods with statistically different climatic variables, i.e. the reference and projected periods. The climate conditions within those periods are represented by statistical estimators, namely the mean value of the meteorological variables, and mean coefficient of variation and coefficient of skewness for the river runoff. In our study, two "quasi-stationary" time periods were adopted: $1950-1990$ as the reference period and 2020-2050 as the projected period.

Hydropower electricity generation accounts for over $48 \%$ of recent renewable energy production in Finland [30]. It is the second most widely exploited renewable energy source in the country. The total unexploited hydropower potential along river systems is estimated to be $2,468 \mathrm{GWh}$. However, only half of that amount is considered economically exploitable [31]. Most of the hydropower plants have no artificial reservoirs to redistribute water year-by-year, and they operate as a run-of-river facility forced by naturally flowing river water through canals or penstocks to spin a turbine [32]. The hydropower production at run-of-river plants depends strongly on river water discharge, since there are no tools to regulate water stream flow.

The study aims to better understand the future extent of water constraints on electricity production in Finland. In this regional study, we selected 12 Finnish river basins to evaluate the probabilistic projections of annual runoff in the near future. These projections were used to estimate patterns for the runoff of rare occurrence in addition to the mean annual runoff. The potential hydropower production was estimated for two hydropower plants to show potential applications in risk assessment for hydropower production in a changing climate.

\section{Materials and Methods}

\subsection{Hydrological Model}

The probabilistic hydrological model was used to simulate the annual runoff values along with their exceedance probability from the projected mean annual precipitation time series [33]. The theoretical equations and limitations of the Advance of Frequency Analysis method are formulated by Kovalenko [26], based on Pugachev et al. [34] in Russian. The main idea of the Advance of Frequency Analysis method is to simulate statistical estimators of multi-year river runoff (mean, variation and skewness) instead of the time series of river discharges. The estimators are estimated from statistics on the precipitation rate and air temperature available in climate scenarios. The estimators of three non-central statistical moments of the annual runoff rate $\left(\mathrm{mm} \mathrm{yr}^{-1}\right)$, were calculated from observations for the period of 1950-1990.

The observations of water surface runoff are usually expressed in volumetric flow rate (water discharge, $\mathrm{m}^{3} \mathrm{~s}^{-1}$ ). In our study, the volumetric rate was converted to the annual runoff rate. The historical yearly time series of annual runoff rate, ARR $\left(\mathrm{mm} \mathrm{yr}^{-1}\right)$ were calculated as follows:

$$
\mathrm{ARR}=1000 Q T / A,
$$

where $\mathrm{Q}$ is the yearly average water discharge, $\mathrm{m}^{3} \mathrm{~s}^{-1}$; $\mathrm{T}$ is the number of seconds in a year, and $\mathrm{A}$ is the catchment area, $\mathrm{m}^{2}$. The non-central moments' estimates were calculated for the period of 1950-1990 from yearly time series of annual runoff rate observed at a gauge with the method of Moments [6, 35]. Then, the non-central moments were used to evaluate the parameters of the Pearson Distribution System (see details in Andreev et al. [36]):

$$
\begin{gathered}
a=0.5\left(5 m_{1} m_{2}-4 m_{1}^{3}-m_{3}\right) /\left(m_{2}-m_{1}^{2}\right), \\
b_{0}=0.5\left(m_{1}^{2} m_{2}-2 m_{2}^{2}+m_{1 r} m_{3}\right) /\left(m_{2}-m_{1}^{2}\right), \\
b_{1}=0.5\left(3 m_{1} m_{2}-2 m_{1}^{3}-m_{3}\right) /\left(m_{2}-m_{1}^{2}\right),
\end{gathered}
$$

where, $\mathrm{m}_{1}, \mathrm{~m}_{2}$ and $\mathrm{m}_{3}$ are the estimates of the non-central statistical moments of the annual runoff rate; $a, b_{0}$ and $b_{1}$ are the parameters of the Pearson Distribution System. The exceedance probability curve of annual runoff rate was constructed within the Pearson type 3 distributions, which commonly applied to estimate water extremes $[6,37,38$, 39].

The parameters $a, b_{0}$ and $b_{1}$ also depend on the statistics of precipitation [26, 29]. To simulate the exceedance probability curve of annual runoff rate for the period of 2020-2050, a, $b_{0}$ and $b_{1}$ are calculated from the mean values of the annual precipitation rate $\left(\mathrm{mm} \mathrm{yr}^{-1}\right)$ over two "quasi-stationary" time periods [26]; in our study, these were 1950-1990 and 2020-2050. The non-central statistical moments of annual runoff rate for the period of 2020-2050 were calculated from the parameters $a, b_{0}$ and $\mathrm{b}_{1}$, assuming that only the mean annual precipitation rate has changed since the reference period [33]. Eventually, 
the non-central statistical moments of annual runoff rate were estimated for the period of 2020-2050 as follows [26, 33]:

$$
\begin{gathered}
m_{1}=a-b_{1}, \\
m_{2}=-b_{0}-2 m_{1} b_{1}+m_{1} a, \\
m_{3}=-2 m_{1} b_{0}-3 m_{2} b_{1}+m_{2} a .
\end{gathered}
$$

In this study, the exceedance probability curve of annual runoff rate were simulated for 12 Finnish river basins from outputs of two climate models under three Representative Concentration Pathways climate scenarios.

The model was cross-validated using the observations on water discharge at 12 gauging sites. For the model cross-validation, the observational time series of annual runoff rate were divide into two sub periods namely the training and control $[26,29]$. The splitting year was corresponded to the year when the statistically significant difference on observations within two periods was detected by the Student and Kolmogorov-Smirnov Tests with length of "moving point/window" equals to 15 years. In case if several splitting years were founded, the maximum year was chosen to divide the observed time series into two periods.

\subsection{Potential Hydropower Production}

Potential hydropower production remains among the traditional indicators for the robust estimate energy production from a known mean of an annual river discharge, a specific head and technological indexes of a hydropower plant [18, 23, 32]. However, focusing solely on the mean value of runoff is not sufficient because risks in hydropower production are posed by runoff extremes $[24,40]$.

The probabilistic projections of annual runoff rate make it possible to evaluate annual runoff rate of any exceedance probability from the simulated exceedance probability curve. In our study, the potential hydropower production $(V$, Watt) was assumed to be linearly related to the annual volumetric flow rate [32]:

$$
V=\rho \alpha H Q,
$$

where $Q$ is the annual volumetric flow rate $\left(\mathrm{m}^{3} \mathrm{~s}^{-1}\right)$ at a plant site, $H$ is a plant-specific hydraulic head (m), and $\rho$ and $\alpha$ are water density $\left(\mathrm{kg} \mathrm{m}^{-3}\right)$ and gravity acceleration $\left(\mathrm{m} \mathrm{s}^{-2}\right)$, respectively. The annual volumetric flow rate at sites of the hydropower plant was estimated after Eq. (1) from the annual runoff rate. In our study, the potential hydropower production was estimated for two middle-sized hydropower plants. The catchment area at both sites was calculated with the on-line service by the Finnish Environmental Institute.

\subsection{Data}

\subsubsection{Precipitation}

There are many sources of meteorological data from around the world that can be used in hydrological applications. Some of them provide observations at sites, while others are the results of interpolations into grid nodes $[41,42]$. In our study, the yearly time series of annual precipitation rate $\left(\mathrm{mm} \mathrm{yr}^{-1}\right)$ were estimated for the grid nodes with a step of 0.5 degree in latitude and longitude, i.e., on the spatial resolution of regional scale climate models. For the period of 1950-1990, the mean values of annual precipitation rate were calculated from the UDel_AirT_Precip data set provided by the National Oceanic and Atmospheric Administration, Boulder, Colorado, USA [41]. For each catchment, the mean values of annual precipitation rate over the period 1960-1990 were taken at the grid nodes located nearest to a catchment centroid.

For the period of 2020-2050, we used the data set of the Coupled Model Inter-comparison Project 5 [43] to evaluate the means of annual precipitation rate from the outputs of the global climate model MPI-ES-LR [44] and the regional climate model RCA4 [45] under three Representative Concentration Pathways (RCP2.6, RCP4.5 and RCP8.5). The mean values of annual precipitation rate over the period 2020-2050 $\left(\mathrm{APR}_{2050}, \mathrm{~mm} \mathrm{yr}^{-1}\right)$ were extracted from the grid point nearest to the catchment centroid in case of the MPI-ESM-LR model, or averaged over the grid nodes within the catchment boundary in case of the RCA4 model. Then the simulated mean values of annual precipitation rate for the historical and projected model runs were delta-corrected [46] for the period 2020-2050.

\subsubsection{River Runoff}

The time series of water discharges were extracted from the Global Runoff Data Center for 12 gauging sites located in Finland for the period of 1911-2015. Figure 1 show the gauging sites selected in this study. 


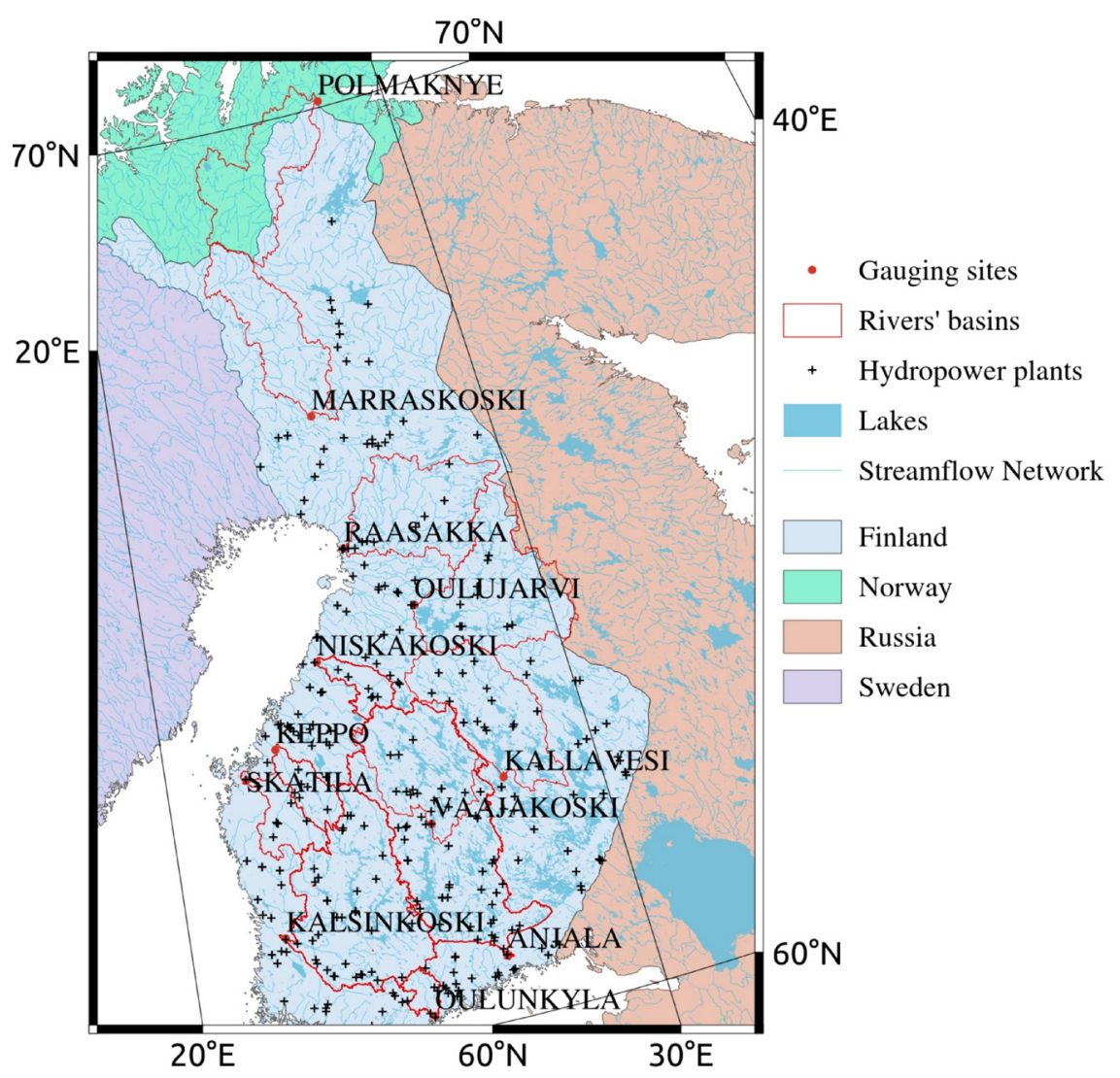

Figure 1. Locations of gauging sites and hydropower stations in 12 Finnish rivers' basins

The runoff data include the mean water discharge $\left(\mathrm{m}^{3} \mathrm{~s}^{-1}\right)$ in a given year at the gauging site as well as the catchments' areas (see Supplements section). The river basin boundaries for the studied gauging sites were also extracted from the Global Runoff Data Center data set as well (see Supplements section). Table 1 shows the names, the catchment areas and lengths of the historical time series for the gauging sites used further.

Table 1. Finnish river basins selected in the study.

\begin{tabular}{|c|c|c|c|c|}
\hline \multirow{2}{*}{ River - Gauge name / Global Runoff Data Center \# } & Lat/ Long & \multirow{2}{*}{ Area, km } & \multicolumn{2}{|c|}{ Observations } \\
\cline { 3 - 5 } & & & Start & End \\
\hline Tana - Polmaknye / 6730501 & $70.1 / 28.0$ & 14160 & 1911 & 2014 \\
\hline Kokemaenjoki - Kalsinkoski / 6854100 & $61.4 / 22.1$ & 26025 & 1931 & 1992 \\
\hline Lapuanjoki - Keppo / 6854200 & $63.4 / 22.7$ & 3949 & 1931 & 2012 \\
\hline Oulunjoki - Oulujarvi / 6854591 & $64.6 / 26.8$ & 19839 & 1950 & 2013 \\
\hline Iljoki - Raasakka / 6854600 & $65.3 / 25.4$ & 14191 & 1911 & 2015 \\
\hline Kemijoki - Marraskoski / 6854710 & $66.8 / 25.4$ & 12303 & 1971 & 2014 \\
\hline Kalajoki - Niskakoski / 6854800 & $64.2 / 24.1$ & 3065 & 1911 & 2011 \\
\hline Kyronjoki - Skatila / 6854900 & $63.1 / 21.9$ & 4833 & 1911 & 2012 \\
\hline Vantaa - Oulunkyla / 6855100 & $60.2 / 24.9$ & 1680 & 1937 & 2013 \\
\hline Kymijoki - Anjala / 6855200 & $60.7 / 26.8$ & 36275 & 1938 & 2015 \\
\hline Kymijoki - Vaajakoski / 6855250 & $62.2 / 25.9$ & 17684 & 1941 & 2013 \\
\hline Vuoksi - Kallavesi / 6855402 & $62.6 / 27.8$ & 16270 & 1931 & 2012 \\
\hline
\end{tabular}




\section{Results}

\subsection{Model Cross-Validation}

The probabilistic hydrological model simulates the estimates of three non-central statistical moments to model exceedance probability curves of annual runoff within the Pearson type 3 distributions. The end-product of the model is the simulated exceedance probability curve; thus there are no time series of river discharges to compare with the observations. In this case, the simulated exceedance probability curve $\mathrm{s}$ is compared to empirical exceedance probability curve $s$ using the Kolmogorov-Smirnov test using a cross-validation procedure [26, 29].

In the cross-validation procedure, the observed time series of runoff is divide into two sub-periods with the training time series and the testing/control time series. The division is done by differences in estimates of mean values for two subperiods evaluated by the Student and Kolmogorov-Smirnov Tests at 0.05 or 0.10 levels of a statistical significance. Then the exceedance probability curve for the control period is constructed from the non-central moments simulated from the annual precipitation rate of the control period. Eventually, the simulated exceedance probability curve for the control period is compared with empirical exceedance probability curve constructed from the non-central moments for the control period. The simulations are done vice versa - from the control period to the training period (see Supplements section). In this study, the model was tested based on the outputs of the regional scale climate model to simulate the hind casts of probabilistic hydrological projections with the cross-validation procedure. We applied the basic scheme by Kovalenko [26] to parameterize the model.

For cross-validation, the annual precipitation rate yearly times series were extracted from the UDel_AirT_Precip data. The mean annual precipitation rate was calculated for the training and control periods. Three parameters of the Pearson System were estimated from the training period, and two of them were considered to be constant for the control period.

Table 2 shows results of the model cross-validation for 12 Finnish river basins. In this case, the Student Test was applied to define the training and control periods on two levels of statistical significance $(\alpha)$. First, $\alpha=0.05$ was tested, and then $\alpha=0.10$ if no split years were detected (see Kyronjoki River at Skatila). In some cases, the split year was not detected on both levels (i.e., Oulunjoki River at Oulujarvi); therefore the cross-validation was not performed. For these catchments, the split year can be defined at the level of significance higher than 0.10 . The Kolmogorov-Smirnov test was as well applied (see Supplements) yielding in general the same results.
Table 2. The statistical level of significance $(\alpha)$ to define the training and control periods $(T)$ together with the statistical significance of the Kolmogorov-Smirnov test values ( $p$-values) of the cross-validation.

\begin{tabular}{|c|c|c|c|c|c|}
\hline \multirow{2}{*}{$\begin{array}{l}\text { River - Gauge } \\
\text { name }\end{array}$} & \multirow{2}{*}{$\alpha$} & \multicolumn{2}{|c|}{ Training period } & \multicolumn{2}{|c|}{ Control period } \\
\hline & & $\mathrm{T}$ & $\mathrm{p}$-value & $\mathrm{T}$ & p-value \\
\hline $\begin{array}{l}\text { Tana River } \\
\text { Polmaknye }\end{array}$ & 0.05 & $\begin{array}{l}1911- \\
1952\end{array}-$ & 0.56 & $\begin{array}{l}1953- \\
2014\end{array}$ & 0.8 \\
\hline $\begin{array}{l}\text { Kokemaenjoki } \\
\text { Kalsinkoski }\end{array}$ & 0.05 & $\begin{array}{l}1931- \\
1975\end{array}$ & 0.44 & $\begin{array}{l}1976 \quad- \\
1992\end{array}$ & 0.93 \\
\hline $\begin{array}{l}\text { Lapuanjoki } \\
\text { Keppo }\end{array}$ & 0.05 & $\begin{array}{l}1931- \\
1993\end{array}-$ & 0.66 & $\begin{array}{l}1994 \quad- \\
2012\end{array}$ & 0.96 \\
\hline $\begin{array}{l}\text { Oulunjoki } \\
\text { Oulujarvi }\end{array}$ & $-1-$ & - & - & - & - \\
\hline $\begin{array}{l}\text { Iljoki } \\
\text { Raasakka }\end{array}$ & 0.05 & $\begin{array}{l}1911- \\
1951\end{array}$ & 0.38 & $\begin{array}{l}1952 \\
2015\end{array}$ & 0.99 \\
\hline $\begin{array}{l}\text { Kemijoki } \\
\text { Marraskoski }\end{array}$ & $-1-$ & - & - & - & - \\
\hline $\begin{array}{l}\text { Kalajoki } \\
\text { Niskakoski }\end{array}$ & 0.05 & $\begin{array}{l}1911- \\
1994\end{array}$ & 0.18 & $\begin{array}{l}1995 \quad- \\
2011\end{array}$ & 0.19 \\
\hline $\begin{array}{l}\text { Kyronjoki } \\
\text { Skatila }\end{array}$ & 0.10 & $\begin{array}{l}1911- \\
1933\end{array}-$ & 0.98 & $\begin{array}{l}1934 \\
2012\end{array}-$ & 0.66 \\
\hline $\begin{array}{l}\text { Vantaa } \\
\text { Oulunkyla }\end{array}$ & $-1-$ & - & - & - & - \\
\hline $\begin{array}{l}\text { Kymijoki } \\
\text { Anjala }\end{array}$ & 0.05 & $\begin{array}{l}1938- \\
1995\end{array}$ & 0.9 & $\begin{array}{l}1996 \\
2015\end{array}$ & 0.77 \\
\hline $\begin{array}{l}\text { Kymijoki } \\
\text { Vaajakoski }\end{array}$ & 0.05 & $\begin{array}{l}1941- \\
1995\end{array}$ & 0.57 & $\begin{array}{l}1996 \quad- \\
2013\end{array}$ & 0.1 \\
\hline $\begin{array}{l}\text { Vuoksi } \\
\text { Kallavesi }\end{array}$ & 0.10 & $\begin{array}{l}1931- \\
1953\end{array}$ & 0.98 & $\begin{array}{l}1954 \\
2012\end{array}$ & 0.62 \\
\hline
\end{tabular}

The training and control periods were defined for the yearly time series of annual runoff rate at 9 gauging sites measuring water discharge in basins with water regulation facilities. Two periods have been detected in the time series of the Tana River at Polmaknye, where is no stream flow regulation in this river basin. Although most selected river basins are regulated by hydropower production facilities (the brown dots in Fig. 1), this regulation does not have an affect the estimations of annual runoff rate since the hydropower plants are middle- or small-sized. Those hydropower plants redistribute river stream flow runoff only within seasons or decades. In our study, the annual runoff rate was considered; thus the effects of water regulations can be considered negligible for the cross-validation procedure.

The longest time series of annual runoff rate are available for Tana River at Polmaknye, with the training period from 1911 to 1952 (Table 1). A similar training period is detected for Iljoki River at Raasakka. The observations of Kemijoki River at Marraskoski started in 1974 (Table 1), and the time series is too short to detect the periods for the cross-validation. The split year is detected in the early 1990s on one-fourth of the gauging sites, which are mostly located in south/central Finland (Table 2, Fig. $1)$. 
In summary, 18 subperiods were used in the cross-validation procedure for 9 selected river basins. The procedure includes comparing the empirical distributions of annual runoff rate and the simulated exceedance probability curve. The p-value (Table 2) indicates the statistical significance of the differences in the exceedance probability curve $\mathrm{s}$ with a null hypothesis of similarity to the exceedance probability curve s. It may be accepted for the most hind casts at the level of significance equal to 0.10 ( $p$-values $>0.10$ in Table 2). Over $83 \%$ of the exceedance probability curve simulations fit the observations on the level of significance equal to 0.20 . These results are generally in accordance with the results given by [26]. In this study, the cross-validation is done using hydrological observations at the river basins and meteorological sites located north of Russia.

\subsection{Model Parameters' Identification}

To evaluate values of the hydrological model's parameters (i.e. to identify the model parameters), the non-central moments' estimates of annual runoff rate and mean values of annual precipitation rate were evaluated for the period of 1950-1990 (Table 3). The non-central moments' estimates were calculated from the yearly time series of annual runoff rate. The yearly values of annual precipitation rate were extracted at the grid point nearest to the catchment centroid (see Supplements).

Table 3. The non-central moments' estimates of annual runoff rate and means of annual precipitation rate for the period of 1950-1990.

\begin{tabular}{|c|c|c|c|c|}
\hline River-Gauge name & $\begin{array}{c}\mathrm{m}_{1}, \\
\mathrm{ym}^{-1}\end{array}$ & $\begin{array}{c}\mathrm{m}_{2}, \\
\mathrm{~mm}^{2} \mathrm{yr}^{-1}\end{array}$ & $\begin{array}{c}\mathrm{m}_{3}, \\
\mathrm{~mm}^{3} \mathrm{yr}^{-1}\end{array}$ & $\begin{array}{c}\mathrm{APR}^{*}, \\
\mathrm{~mm} \mathrm{yr}^{-1}\end{array}$ \\
\hline $\begin{array}{c}\text { Tana - Polmaknye } \\
\begin{array}{c}\text { Kokemaenjoki - } \\
\text { Kalsinkoski }\end{array}\end{array}$ & 271 & 142063 & 56005162 & 381 \\
\hline Lapuanjoki-Keppo & 270 & 79596 & 25505369 & 533 \\
\hline Oulunjoki-Oulujarvi & 345 & 123093 & 45181503 & 589 \\
\hline Iljoki-Raasakka & 386 & 154331 & 63672500 & 616 \\
\hline $\begin{array}{c}\text { Kemijoki- } \\
\text { Marraskoski }\end{array}$ & 324 & 108233 & 37194948 & 489 \\
\hline Kalajoki-Niskakoski & 277 & 82387 & 26032367 & 456 \\
\hline Kyronjoki-Skatila & 292 & 93765 & 33068450 & 533 \\
\hline Vantaa / Oulunkyla & 314 & 107240 & 39934251 & 647 \\
\hline Kymijoki- Anjala & 255 & 68709 & 19322343 & 625 \\
\hline $\begin{array}{c}\text { Kymijoki- } \\
\text { Vaajakoski }\end{array}$ & 277 & 79946 & 24037500 & 572 \\
\hline Vuoksi-Kallavesi & 319 & 106486 & 36880077 & 612 \\
\hline
\end{tabular}

* Annual precipitation rate
The mean values of annual precipitation rate were calculated from the gridded data, and we compared them to the estimates calculated from observations at the nearest meteorological stations. Generally, the values of gridded annual precipitation rate match the stations' data. For instance, Kivinen et al. [47] estimate that the mean annual precipitation amount at Sodankyla station to be $489 \mathrm{~mm}$ $\mathrm{yr}^{-1}$ for the period of 1914-2013, which is in accordance with the estimation for Kemijoki River at Marraskoski (485 $\mathrm{mm} \mathrm{yr}^{-1}$, see Table 2).

\subsection{Climate Projections}

\subsubsection{Precipitation}

The mean values of annual precipitation rate $\left(\mathrm{mm} \mathrm{yr}^{-1}\right)$ over the period 2020-2050 were obtained from the outputs of the MPI-ESM-LR global climate model as well as the RCA4 regional climate model under the RCP2.6, RCP4.5 and RCP8.5 scenarios. The mean values of annual precipitation rate were extracted from the grid point nearest to the catchment centroid in case of the global model or averaged over the grid nodes within the catchment boundary in case of the regional model. Table 4 shows the mean annual precipitation rate estimated for the catchments selected. (See details in Supplements section.)

Table 4. The mean values of annual precipitation rate for the period of 2020-2050.

\begin{tabular}{|c|c|c|c|c|c|c|}
\hline \multirow{2}{*}{ River - Gauge name } & \multicolumn{3}{|c|}{ RCA4 } & \multicolumn{3}{|c|}{ MPI-ESM-LR } \\
\hline & $26^{*}$ & 45 & 85 & 26 & 45 & 85 \\
\hline Tana - Polmaknye & 358 & 349 & 364 & 374 & 415 & 428 \\
\hline $\begin{array}{l}\text { Kokemaenjoki - } \\
\text { Kalsinkoski }\end{array}$ & 510 & 517 & 515 & 655 & 675 & 675 \\
\hline Lapuanjoki - Keppo & 459 & 457 & 463 & 549 & 572 & 556 \\
\hline Oulunjoki - Oulujarvi & 517 & 497 & 532 & 614 & 651 & 696 \\
\hline Iljoki - Raasakka & 525 & 489 & 525 & 625 & 695 & 737 \\
\hline $\begin{array}{l}\text { Kemijoki - } \\
\text { Marraskoski }\end{array}$ & 433 & 422 & 440 & 508 & 562 & 577 \\
\hline Kalajoki - Niskakoski & 437 & 420 & 439 & 476 & 487 & 492 \\
\hline Kyronjoki - Skatila & 496 & 498 & 501 & 549 & 572 & 555 \\
\hline Vantaa / Oulunkyla & 549 & 572 & 555 & 669 & 696 & 689 \\
\hline Kymijoki - Anjala & 514 & 518 & 524 & 579 & 623 & 694 \\
\hline $\begin{array}{l}\text { Kymijoki - } \\
\text { Vaajakoski }\end{array}$ & 500 & 493 & 507 & 660 & 672 & 654 \\
\hline Vuoksi-Kallavesi & 535 & 524 & 553 & 630 & 679 & 726 \\
\hline
\end{tabular}

* the outputs of the climate models under the RCP2.6 (26), RCP4.5 (45) and RCP8.5 (85) scenarios.

The regional climate model was averaged over the grid nodes located within the catchment boundary. In case of Vantaa River, there was not any grid node located within 
the boundary, even for the output of the RCA4 model. In this case, we extracted the mean value of annual precipitation rate in the grid node nearest to the catchment's centroid. Figure 2 shows how the mean values of annual precipitation rate will be changed in the period of 2020-2050 compared to the period of 1950 1990. In Fig. 2, the rivers' basins are coloured according to the expected changes in the mean of annual precipitation rate: the red colour indicates an increase in annual precipitation rate, while the blue colour indicates a decrease in annual precipitation rate. These colours only mark the relative changes for more than $10 \%$, and the green colour indicates relative changes within $10 \%$ (or no "valuable" changes).
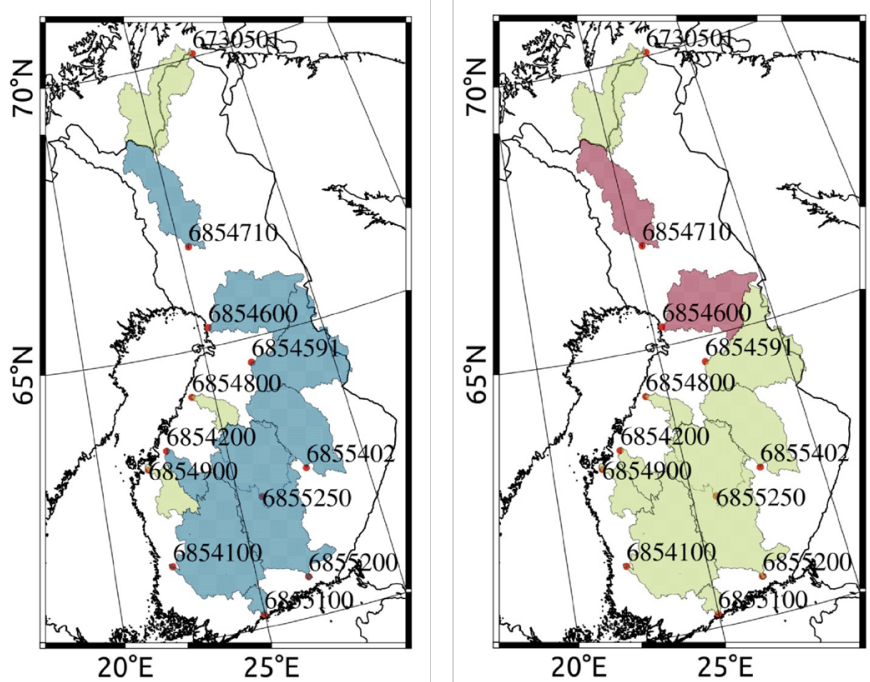

Figure 2. The relative changes in the mean annual precipitation rate $\left(\mathrm{mm}_{\mathrm{yr}} \mathrm{-}^{-1}\right)$ expected according to the RCA4 model (left) and after the MPI-ESM-LM model (right): red/blue - to increase/decrease, green - no valuable changes.
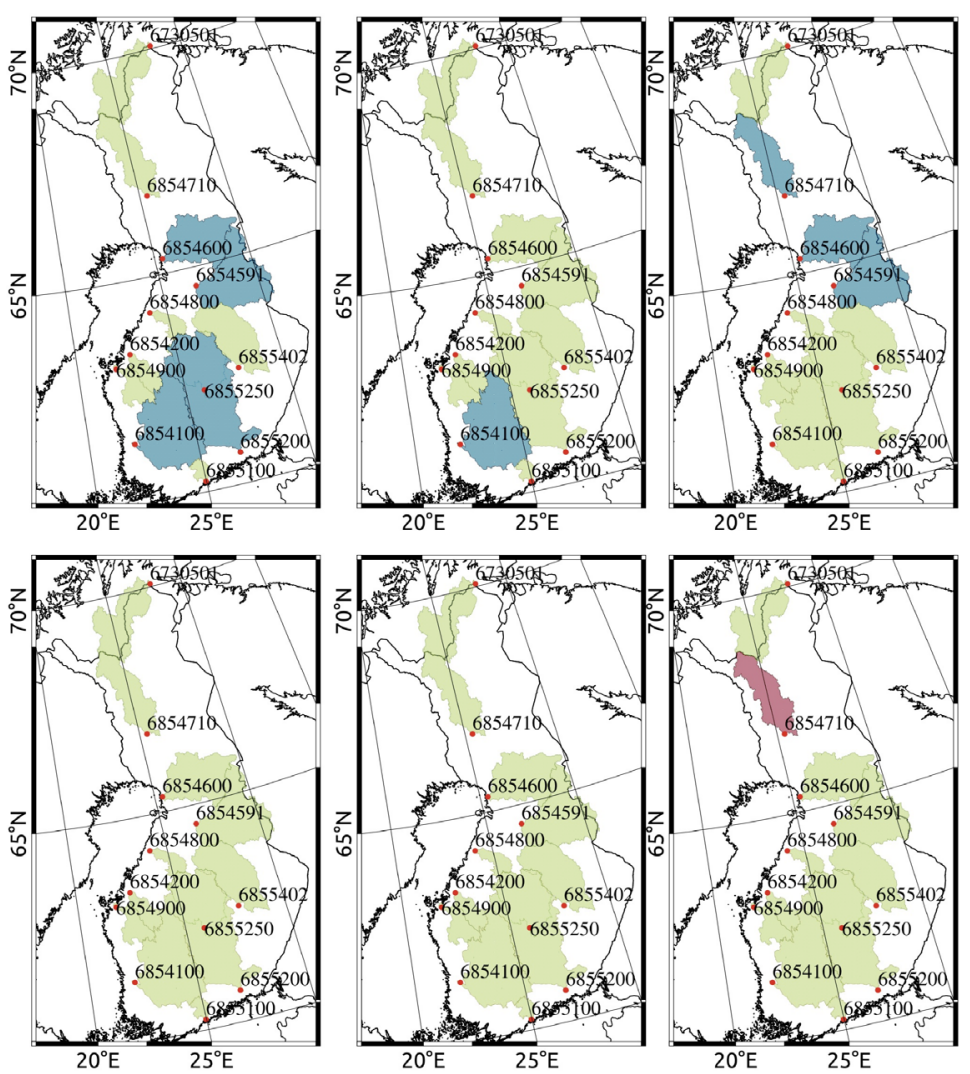

Figure 3. The relative changes in annual runoff rate according to the RCA4 model (top) and after the MPI-ESM-LM model (bottom): red/blue = to increase/decrease, green $=$ no valuable changes. In columns from left to right: $\mathrm{ARR}_{50}, \mathrm{ARR}_{10}$ and $\mathrm{ARR}_{90}\left[\mathrm{~mm} \mathrm{yr}^{-1}\right]$. 
In Fig. 2, only the results for the RCP45 climate scenario ("middle way" in the family of the Representative Concentration Pathways) for the period of 2020-2050 are presented. The means of annual precipitation rate are expected to decrease according to the RCA4 model for most river basins considered (the blue-coloured areas in Fig. 2, left). The MPI-ESM-LM model suggests an increase in the mean annual precipitation rate for only two catchments: Kemijoki River at Marraskoski and Ilijoki River at Raasaka (the red-coloured areas in Fig. 2, right). In our study, two climate models suggested different trends for future changes in the annual precipitation rate: according to the global model, the precipitation increases, whereas the regional model indicates precipitation decrease.

Ruosteenoja et al. [48] make a summary for Finland of the expected changes in the annual precipitation rate according to the climate projections for the period of 2020 2049. The authors estimate that the annual precipitation rate is expected to increase by $5-7 \%$ on average over most territory of Finland, whereas the ensembles of the climate of models in the CMIP5 suggest an increase up to $12 \%$. In our study, similar results were obtained. The means of annual precipitation rate are expected to increase in three RPC scenarios according to the outputs of the global model. This increase in precipitation for the period of 2020-2050 is below $10 \%$ for most river basins (Fig. 2, right).

\subsubsection{River Runoff}

In our study, the probabilistic projections of annual runoff rate were evaluated from the means of annual precipitation rate simulated by two climate models. The probabilistic projection of annual runoff rate is the exceedance probability curve constructed within the Pearson type 3 distributions. The exceedance probability curve allows an estimation of runoff values along with their exceedance probability. We only shown results for the annual runoff rate values with $10 \%$ and $90 \%$ exceedance probabilities $\left(\mathrm{ARR}_{10} / \mathrm{ARR}_{90}\right)$ in additional to the mean values $\left(\mathrm{ARR}_{50}\right)$. Those values were simulated from the outputs of the global and regional climate models (see Supplements).

Figure 3 shows how the values of annual runoff rate with $10 \%, 50 \%$ and $90 \%$ exceedance probabilities will change due to the means of annual precipitation rate estimated from two climate models. The $\mathrm{ARR}_{50}, \mathrm{ARR}_{10}$ and $\mathrm{ARR}_{90}$ are presented from left to right in the columns in Fig. 3. The rows in Fig. 3 show two runoff projections for the regional scale RCA4 (top) and the global scale MPI-ESM-LM (bottom) climate models. In the Fig. 3, the Finnish rivers' basins are classified into three groups according to a range of changes in the annual runoff rate values.

The classification we apply is associated with modelling uncertainties. The modelling uncertainties include the uncertainties inherent in the Advance of Frequency Analysis method [26, 29] as well as the uncertainties due to the quality of climate and runoff data sets used to evaluate non-central moments' estimates for the runoff and means of precipitation. In our study, we assess only the modelling uncertainties inherent in the Advance of Frequency Analysis method. Thus, relative changes over $15 \%$ for the $\mathrm{ARR}_{50}$ (Fig. 3 left column) and over $20 \%$ for the $\mathrm{ARR}_{10}$ and $\mathrm{ARR}_{90}$ (Fig. 3 middle and right columns, respectively) were considered to be valuable. They are marked by the red/blue colours in Fig. 3.

According to the regional model RCA4, a decrease of annual runoff rate is expected to occur for most river basins (see Fig. 3 top from left to right for the $\mathrm{ARR}_{50}, \mathrm{ARR}_{10}$ and $A R R_{90}$ ). This regional model suggests a decrease in annual precipitation rate (Fig. 2, left), while the global model MPI-ESM-LM yields a slight increase of the means of annual precipitation rate. For the most rivers' basins in Finland, there is no pronounced increase (Fig. 2, right). Under the annual precipitation rate changes suggested by the global model, no significant changes of the $\mathrm{ARR}_{50}$ and $\mathrm{ARR}_{10}$ are expected in the selected rivers' basins (see Fig. 3 bottom left and middle draws). Only for the basin of Kemijoki River at Marraskoski (the red-coloured area), the increase in $\mathrm{ARR}_{90}$ over $20 \%$ is expected for the period of 2020-2050. The runoff values with high exceedance probabilities are associated with the "river base flow" [39] sustaining a river runoff during "low precipitation" seasons such as summer and winter in Finland.

\subsection{Potential Hydropower Production}

In our study, the potential hydropower production was estimated for two hydropower plants located at the basin of Oulunjoki River (Fig. 4). We have selected two middle-sized hydropower plants located upstream and downstream of the Oulujarvi gauge at, for wich the observed time series is available. The Montta hydropower plant has been in operation since 1957. It has a dam head of $12.2 \mathrm{~m}$. Annual electricity generation covers demands of more than 9,000 households in Finland [49]. The Koivukoski III hydropower plant was built in 1995 and its head is about 15-17 m [50]. The catchment area of Oulunjoki River at the plant's sites was calculated with the on-line service by the Finnish Environmental Institute [51]. Oulunjoki River has a catchment area of over $21,518 \mathrm{~km}^{2}$ at the Montta plant location, and over $7,475 \mathrm{~km}^{2}$ at the site of Koivukoski III.

The Oulunjoki River basin is delineated by the Finnish Environmental Institute at Merikoski site (red line in Fig. 3). Apart from that, the Global Runoff Data Center provides its own estimation for the Oulunjoki River basin boundary at Oulujarvi site (blue line in Fig. 3). There is disagreement on the delineation according to these two data sources. The Global Runoff Data Center suggests the river basin area outside the Finnish-Russian boundary, in accordance with [52]. However, according to the Finnish Environmental Institute [53], the catchment of Oulunjoki River lies completely within Finnish territory. It results in the difference in the area estimation of more than $1000 \mathrm{~km}^{2}$ at the site of Oulunjarvi for those two data sources. 


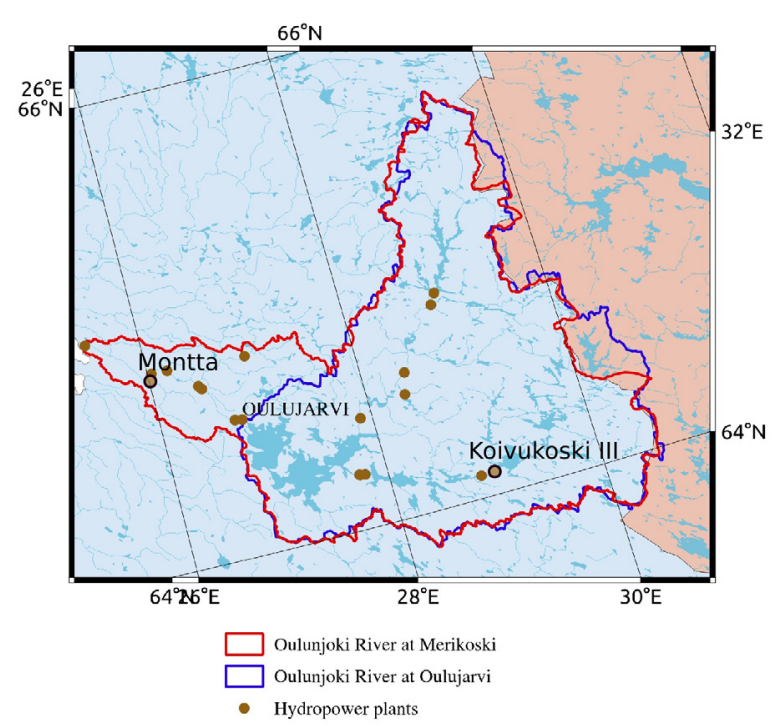

Figure 4. The hydropower plants located at the basin of Oulunjoki River.

The potential hydropower production was estimated from water river discharges with 10,50 and $90 \%$ exceedance probabilities (Table 5). Since there are no observed time series of water discharge at the sites of the Montta and Koivukoski III hydropower plants available in Global Runoff Data Center; therefore the water river discharges were calculated from Eq. (1), based on the projections of annual runoff rate for the period of 2020 2050.

Table 5. The hydropower production $(V)$ at the sites of two plants

\begin{tabular}{|c|c|c|c|c|}
\hline \multirow{2}{*}{ Period } & \multicolumn{2}{|c|}{ Montta } & \multicolumn{2}{c|}{ Koivukoski III } \\
\cline { 2 - 5 } & $\mathrm{Q}^{*}, \mathrm{~m}^{3} \mathrm{~s}^{-1}$ & $V, \mathrm{MW}$ & $\mathrm{Q}, \mathrm{m}^{3} \mathrm{~s}^{-1}$ & $V, \mathrm{MW}$ \\
\hline $\begin{array}{c}\text { 1950-1990: } \\
\text { observations }\end{array}$ & $\begin{array}{c}290 / 235 / \\
180\end{array}$ & $\begin{array}{c}34.7 / 28.2 / \\
21.6\end{array}$ & $\begin{array}{c}101 / 81.8 / \\
62.6\end{array}$ & $\begin{array}{c}15.8 / 12.8 / \\
9.82\end{array}$ \\
\hline 2020-2050: & $314 / 260 /$ & $37.6 / 31.1$ & $109 / 90.3 /$ & $17.1 / 14.2 /$ \\
MPI-ESM-LR & 205 & $/ 24.6$ & 71.3 & 11.2 \\
\hline 2020-2050: & $253 / 199 /$ & $30.3 / 23.8 /$ & $87.9 / 68.9 /$ & $13.8 / 10.8 /$ \\
RCA4 & 143 & 17.1 & 49.5 & 7.78 \\
\hline
\end{tabular}

* $\mathrm{Q}$ is water discharge. Three numbers indicate the values of $10 \%, 50 \%$ and $90 \%$ exceedance probabilities.

Potential hydropower production was evaluated from the water discharges at the sites of the Montta and Koivukoski III hydropower plants (Table 5). It was assumed that potential hydropower production is simply related to the water discharge in all ranges of exceedance probability. Electricity production at a plant is less than the potential hydropower production, and it depends on regulation rules and generation technology [32]. Electricity production at the Montta hydropower plant is $47 \mathrm{MW}$ [49], and it is over $20 \mathrm{MW}$ at Koivukoski III [50]. Thus, the mean water discharge can be roughly evaluated from Eq. (5) from the known capacity for each site. In this case, the mean water discharge was about half of the mean water discharge after the method of Moments for both hydropower sites (Table 5, for the period of 1960-1990).

\section{Discussion}

Nowadays, a vision of future climate is changing continuously, mainly because of the advances in climate modelling. Climate projections are updated almost every 3-6 years for meteorological parameters [42, 43, 54], and a new generation of projections is about to be released soon [55]. In view of that the availability of hydrological models capable to quickly assess the effects of climate on water resources based on meteorological projections gains in importance. The lumped or semi-distributed physically-based hydrological models are traditionally applied at a short term or seasonal scale to simulate runoff times series from time series of meteorological variables [56].

In hydrological studies focused on multiple catchments those models are driven by outputs of climate models or model ensembles in order to evaluate water resources and extremes of runoff in the future on a catchment scale [57, $58,59]$. The simulation of the runoff time series from the time series of meteorological variables (see Fig. 2 by Veijalainen et al. [57]) leads to high computational costs of estimations of water extremes that need to be served in terms of probability in economical applications [60].

The probabilistic hydrological model [33] applied in our study is computationally cheaper compare to lumped or semi-distributed physically based hydrological models. It can be easy coupled with global and regional climate models in order to provide a "quick analysis" of water extremes under any current version of future climate. The main feature of the model is that it simulates the exceedance probability curve of river runoff instead of the time series. This form of hydrological prediction was named as the probabilistic projection of runoff.

In our study, we assumed the "quasi-stationary" for the expected climate change $[26,33,61,62]$. In this case, the climate is described by statistical estimators i.e., mean value, variability, etc., of precipitation, air temperature, evapotranspiration, river runoff, etc., for a period of $20-40$ year. It is assumed to consider two time periods with "statistically" different climates.

The cross-validation of the probabilistic hydrological model has some specific features: it requires defining two observational periods with a statistically significant difference in the exceedance probability curve parameters [26]. In this study, the "floating point/window" algorithms were applied to detect the split year on the level of significance of 0.05 widely accepted in water engineering $[6,7]$. Apart from that, we used the level of significance of 0.10 to define the splitting year in the observations (i.e. Oulunjoki at Oulujarvi) as needed for the cross validation 
procedure. However, it is not clear how the level of statistical significance affects detection of the splitting year, as well as the chosen length of "floating point/window. In this study, a 15-year "floating point/window" was used. It would consider these and other issues connected to the model cross-validation separately.

For better understanding of the effects of the spatial resolution of the climate forcing on the results of the modelling, the regional climate model RCA4 was used in additional to the global climate model MPI-ESM-LR. In this study, the increase in spatial resolution does not affect the model cross-validation results (Table 4 and Supplements).

In this study, we used the data of the Coupled Model Inter-comparison Project 5, CMIP5 [43] as well as the EURO-CORDEX [63] collection of climate projections under three Representative Concentration Pathways according to the Fifth Assessment Report (AR5). The expected changes in the annual runoff rate for 12 river basins located in Finland were evaluated from annual precipitation rate under these climate scenarios. The probabilistic projections of annual runoff rate were evaluated for $\pm 10-12 \%$ changes in the future annual precipitation rate. The model's simulations were depicted well in both directions for an increase/decrease in the annual precipitation rate.

Potential hydropower production was evaluated in the example of two plants located in the Oulujoki River basin. We found out that our estimations twofold smaller than those given in the plants' description [50, 51]. In our opinion, this disagreement can be explained by the application of different methods. Our results in Table 5 include the assessment of the systematic uncertainty of methods and data behind a delineation of the river basins. The observations at the sites of the Montta and Koivukoski II plants makes it possible to improve our estimations of the potential hydropower production.
In our study, we applied the assumption that the annual runoff rate is linearly related to the potential hydropower production for all exceedance probabilities. This assumption allows to evaluate the risks associated with the annual runoff of low (10\%) and high (90\%) exceedance probability. In our opinion, probabilistic hydrological projection methods are useful tools in the risk assessment for a potential hydropower production and have advantages for water engineering compared to the hydrological models with higher computational costs, however, a further study is needed for the development of probabilistic approach.

\section{Conclusions}

The probabilistic projections of annual runoff rate for the period of 2020-2050 were evaluated for 12 Finnish river basins. We used two climate models with different spatial resolution to investigate the effects of the model resolution on the projected precipitation change and the simulation of the parameters of exceedance probability curves of runoff in the probabilistic hydrological model. We found out that an increase of the spatial resolution of climate models does not affect the results of the runoff simulations.

\section{Supplements}

This study is based on open source data collected for 12 gauging sites located in Finland which are given here as the supplements to this study along with the step-by-step modeling results. . The supplements are hosted by GitHub: https://github.com/ElenaShe000/MARCS/tree/HPFIN and accompanied by detailed descriptions. Table 6 shows the files downloaded from the CMIP5/EURO-CORDEX data collections.

Table 6. Names of the files extracted from the CMIP5 and CORDEX data sets.

\begin{tabular}{|c|c|}
\hline Name of the climate model & Name of the files \\
\hline PI-ESM-LR & $\begin{array}{l}\text { (pr_Amon_MPI-ESM-LR*)_historical_rli1p1_185001-200512.nc } \\
\text { (*)_rcp26_rli1p1_200601-210012.nc } \\
\text { (*)_rcp45_rli1p1_200601-210012.nc } \\
\text { (*)_rcp85_rli1p1_200601-210012.nc }\end{array}$ \\
\hline RCA4 & $\begin{array}{l}\text { (pr_EUR-44i_MPI-M-MPI-ESM-LR_historical_r1i1p1_SMHI-RCA4_v1_mon*)_195101-196012.nc } \\
\text { (*)_196101-197012.nc } \\
\text { (*)_197101-198012.nc } \\
\text { (*)_198101-199012.nc } \\
\text { (*)_199101-200012.nc } \\
\text { (*)_200101-200512.nc }\end{array}$ \\
\hline
\end{tabular}




\section{Acknowledgements}

The study is supported by the Academy of Finland (contract number 283101). Our special thanks to Matti Horttanainen, Ekaterina Kurzeneva and Oxana Savoskul.

\section{REFERENCES}

[1] D. Schwanenberg, M. Xu, T. Ochterbeck, C. Allen, D. Karimanzira. Short-term management of hydropower assets of the Federal Columbia River Power System, Journal of Applied Water Engineering and Research, Vol. 2, 25-32, 2014.

[2] C. E. M. Tucci, W. Collischonn, R. T. Clarke, A. R. Paz, D. Allasia. Short and long term flow forecasting in the Rio Grande watershed (Brazil), Atmospheric Science Letters, Vol. 9, 53-56, 2008.

[3] W. C. Xu, Y. Zhang, G. Fu Peng, H. Zhou. A two stage Bayesian stochastic optimization model for cascaded hydropower systems considering varying uncertainty of flow forecasts, Water Resource Research, Vol. 50, 9267 9286, 2014

[4] WMO-\#168: Guide to hydrological practices. Vol. II: Management of water resources and application of hydrological practices, World Meteorological Organization (WMO), Geneva, Switzerland, 2009.

[5] K.R. Mylne. Decision-making from probability forecasts based on forecast value, Meteorological Applications, Vol. 9, 307-315, 2002.

[6] A.V. Rogdestvenskiy, A.I. Chebotarev. Statistical methods in hydrology, Gidrometeizdat, Leningrad, USSR, 1974. (In Russian)

[7] M. A. Benson. Uniform Flood Frequency Estimating Methods for Federal Agencies, Water Resour. Res., 4(5), 891-908, 1968.

[8] Bulletin 17-B: Guideline for determining flood flow frequency, U.S. Geological Survey, Virginia, USA, 1982.

[9] A. S. Monin. An Introduction to the Theory of Climate, Reidel, Dordrecht, 1986.

[10] D. L. Hartmann, et al. Observations: Atmosphere and surface, in Climate Change 2013: The Physical Science Basis. Contribution of Working Group I to the Fifth Assessment Report of the Intergovernmental Panel on Climate Change, edited by T. F. Stocker et al., Cambridge Univ. Press, Cambridge, U. K., and New York, 2013.

[11] T. Rosmann, E. DOMÍNGUEZ, J. Chavarro. Comparing trends in hydrometeorological average and extreme data sets around the world at different time scales, Journal of Hydrology: Regional Studies, Vol. 5, 200-212, 2016.

[12] T. Prowse, A. Bring, J. Mård, E. Carmack, M. Holland, A. Instanes, T. Vihma, F. J. Wrona. Arctic Freshwater Synthesis: Summary of key emerging issues, Journal Geophysical Research Biogeoscience, Vol. 120, 1887-1893, 2015.
[13] T. Vihma, J. Screen, M. Tjernström, B. Newton, X. Zhang, V. Popova, C. Deser, M. Holland, T. Prowse. The atmospheric role in the Arctic water cycle: A review on processes, past and future changes, and their impacts, Journal Geophysical Research Biogeoscience, Vol. 121, 586-620, 2016.

[14] Roshydromet: Second Assessment Report on Climate Change and its Consequences in Russian Federation. General Summary, Roshydromet Federal Service for Hydrometeorol. and Environ. Monit., Moscow, Russia, 2014.

[15] Y. I. Aleksandrov, N.N. Bryazgin, E. J. Førland, V. F. Radionov, P.N. Svyashchennikov. Seasonal, interannual and longterm variability of precipitation and snow depth in the region of the Barents and Kara seas. Polar Research, Vol. 24(1-2), 69-85, 2005.

[16] Norden, 2018: 10 Insights into the Nordic energy system. Online Available: http://www.nordicenergy.org/wp-conten t/uploads/2018/06/10-Insights-A4.pdf

[17] WMO-\#385: International glossary of hydrology. World Meteorological Organization (WMO), Geneva, Switzerland, 2012.

[18] S. C. Parkinson, N. Djilali. Robust response to hydro-climatic change in electricity generation planning, Climatic Change, 130, 475-489, 2015.

[19] M. T. H. van Vliet, D. Wiberg, S. Leduc, K. Riahi. Power-generation system vulnerability and adaptation to changes in climate and water resources. Nature Climate Change, Vol. 6, 375-380, 2016.

[20] P. Seljom, E. Rosenberg, A. Fidje, J. Haugen, M. Meir, J. Rekstadand, T. Jarlset. Modelling the effects of climate change on the energy system-A case study of Norway, Energy Policy, Vol. 39, 7310-7321, 2011.

[21] B. Lehner, G. Czisch, S. Vassolo. The impact of global change on the hydropower potential of Europe, Energy policy, Vol. 33(7), 839-855, 2005.

[22] K. Madani, J.R. Lund,. Estimated impacts of climate warming on California's high-elevation hydropower. Climatic Change, Vol. 102, 521-538, 2010.

[23] B. Hamududu, A. Killingtveit. Assessing of Climate Change Impacts on Global Hydropower, Energies, 5(2), 305-322, 2012.

[24] P. Döll, F. Kasparand, B. Lehner. A global hydrological model for deriving water availability indicators: model tuning and validation, Journal of Hydrology, Vol. 270 (1-2), 105-134, 2003.

[25] P. Milly, J. Betancourt, M. Falkenmark, R. M. Hirsch, Z. W. Kundzewicz, D. P. Lettenmaier, R.J. Stouffer. Stationarity is dead: whither water management, Science, Vol. 319, 573-574, 2008.

[26] V. V. Kovalenko. Modelling of hydrological processes, Gidrometeizdat, St. Petersburg, Russia, 1993. (In Russian).

[27] N. V. Viktorova, M. N. Gromova. Long-term forecasting of characteristics of minimal river runoff discharges in Russia in case of possible climate change, Russian Meteorology and Hydrology, 33(6), 388-393, 2008. 
[28] T. ROSMANN, E. DOMÍNGUEZ. A Fokker-PlanckKolmogorov equation-based inverse modelling approach for hydrological systems applied to extreme value analysis, Journal of Hydroinformatics, jh2017079, 2017.

[29] E. Shevnina, E. Kourzeneva, V. Kovalenko, T. Vihma. Assessment of extreme flood events in a changing climate for a long-term planning of socio-economic infrastructure in the Russian Arctic, Hydrology and Earth System Science, Vol. 21, 2559-2578, 2017.

[30] Official Statistics of Finland: Production of electricity and heat, Appendix figure 2. Electricity generation with renewables. Online Available: http://www.stat.fi/til/salatuo/2017/salatuo 2017 2018-11-01_kuv_002 en.html

[31] World Energy Council. Online Available: https://www.worl denergy.org/data/resources/country/finland/hydropower/.

[32] V. I. Obrezkov. Hydroenergy: a handbook for engineers, Moscow, Energoizdat, 1988. (In Russian).

[33] E. Shevnina, A. Silaev. The probabilistic hydrological model MARCS (MARkov Chain System): the theoretical basis for the core version 0.2, Geoscientific Model Development: Discussion, 2018.

[34] V. S. Pugachev, I. E. Kazakov, L. G. Evlanov. Basics of statistical theory of automatic system, Mashinostroenie, Moscow, USSR, 1974. (In Russian).

[35] P. van Gelder, W. Wang, J. K. Vrijling. STATISTICAL ESTIMATION METHODS FOR EXTREME HYDROLOGICAL EVENTS, in: New Concepts for Security, NATO Science Series, 78, Springer, Dordrecht, 2006.

[36] A. Andreev, A. Kanto, P. Malo. Simple approach for distribution selection in the Pearson System, Helsingin kauppakorkeakoulu, Finland, 2005.

[37] I. A. Koutrouvelis, G. C. Canavos. Estimation in the Pearson type 3 distributions, Water Resource Research, 35(9), 2693-2704, 1999.

[38] N. C. Matalas, J. R. Wallis. Eureka! It fits a Pearson type: 3 distributions, Water Resource Research, 9(2), 281-289, 1973.

[39] D.L. Sokolovskiy. River runoff (bases on a theory and methods of calculations). Leningrad, Hydrometeoidat, 1968. (in Russian)

[40] P. Milly, K.A. Dunne, A.V. Vecchia. Global pattern of trends in streamflow and water availability in a changing climate, Nature, Vol. 438, 347-350, 2005.

[41] NOAA/OAR/ESRL PSD, Boulder, Colorado, USA. Online Available: http://www.esrl.noaa.gov/psd/.

[42] M.J. Menne, I. Durre, R.S. Vose, B.E. Gleason, T.G. Houston. An overview of the Global Historical Climatology Network-Daily Database, Journal of Atmospheric and Oceanic Technology, Vol. 29, 897-910, 2012.

[43] K. E. Taylor, R. J. Stouffer, G.A. Meehl. An overview of CMIP5 and the experiment design, Bulletin of American Meteorological Society, 93,485-498, 2012.

[44] D. Popke, B. Stevens, A. Voigt. Climate and climate change in a radiative-convective equilibrium version of ECHAM6,
Journal of Advances in Modeling Earth Systems, Vol.. 5, $1-14,2013$.

[45] G. Strandberg, L. Bärring, U. Hansson, C. Jansson, C. Jones, E. Kjellström, M. Kolax, M. Kupiainen, G. Nikulin, P. Samuelsson, A. Ullerstig, S. Wang. CORDEX scenarios for Europe from the Rossby Centre regional climate model RCA4, Technical report. Online Available: https://www.smhi.se/en/p ublications/cordex-scenarios-for-europe-from-the-rossby-centr e-regional-climate-model-rca4-1.90274

[46] H. J. Fowler, S. Blenkinsop, C. Tebaldi. Linking climate change modelling to impacts studies: recent advances in down-scaling techniques for hydrological modelling, Int. Journal of Climatology, 27(12), 1547-1578, 2007.

[47] S. Kivinen, S. Rasmus, K. Jylhä, M. Laapas. Long-Term Climate Trends and Extreme Events in Northern Fennoscandia (1914-2013). Climate. 5(1), 162017, 2017.

[48] K. Ruosteenoja, K. Jylhä, M. Kämäräinen. Climate projections for Finland under the RCP forcing scenarios, Geophysica, Vol, 51 (1), 17-50, 2016.

[49] Fortum hydropower stations. Online Available: https://www.fortum.com/about-us/our-company/our-energy-p roduction/our-power-plants/oulujoki-river-system

[50] Koivukoski III:https://fi.wikipedia.org/wiki/ Koivukoski_III (in Finnish)

[51] A catchment delineation at a site located in Finland: http://paikkatieto.ymparisto.fi/value/

[52] HELCOM maps:http://maps.helcom.fi/website/mapservice/in dex.html

[53] The delineation procedure and data by the Finnish Environmental Institute: https://www.syke.fi/fi-FI/Tutkimus kehittaminen/Vesi/Tietoaineistot_ja_jarjestelmat/Valumaaluej arjestelma/Uusi_valumaaluejako (in Finnish)

[54] V. Eyring, S. Bony, G. A. Meehl, C. A. Senior, B. Stevens, R. J. Stouffer, K. E. Taylor. Overview of the Coupled Model Intercomparison Project Phase 6 (CMIP6) experimental design and organization, Geoscientific Model Development, Vol. 9, 1937-1958, 2016

[55] IPCC. Online Available: https://www.ipcc.ch/reports/

[56] C. Teutschbein, J. Seibert. Regional Climate Models for Hydrological Impact Studies at the Catchment Scale: A Review of Recent Modelling Strategies, Geography Compass, Vol. 4 (7), 834-860, 2010.

[57] N. Veijalainen, J. Korhonen, B. Vehviläinen, H. Koivusalo. Modelling and statistical analysis of catchment water balance and discharge in Finland in 1951-2099 using transient climate scenarios, Journal of Water and Climate Change, Vol. 3, 55-78, 2012.

[58] B. Arheimer, G. Lindström. Climate impact on floods: changes in high flows in Sweden in the past and the future (1911-2100), Hydrology and Earth System Science, 19, 771-784, 2015.

[59] J. Seibert. Conceptual runoff models - fiction or representation of reality? comprehensive Summaries of Uppsala Dissertations from the Faculty of Science and Technology, 436, Sweden, 1999. 
[60] A.H. Murphy. Decision-making models in the cost-loss ratio situation and measures of the value of probability forecasts, Monthly Weather Review, 104, 1058-1065, 1976.

[61] V. V. Kovalenko, N. V. Victorova, E. V. Gaydukova, M. A. Gromova, V. A. Khaustov, E. V. Shevnina. Guideline to estimate a multi-year runoff regime under non-steady climate to design hydraulic contractions, Russian State Hydrometeorologcial University, St. Petersburg, 2010. (In Russian).

[62] V.V. Kovalenko. HYDROLOGICAL security OF BUILDING PROJECTS WITH CLIMATE CHANGE, Russian State Hydrometeorological University Press, St. Petersburg, Russia, 2009. (In Russian).

[63] D. Jacob, J. Petersen, B. Eggert, A. Alias, O. B. Christensen, L. M. Bouwer, A. Braun, A. Colette, M. Déqué, G. Georgievski, E. Georgopoulou, A. Gobiet, L. Menut, G. Nikulin, A. Haensler, N. Hempelmann, C. Jones, K. Keuler, S. Kovats, N. Kröner, S. Kotlarski, A. Kriegsmann, E. Martin, E. van Meijgaard, C. Moseley, S. Pfeifer, S. Preuschmann, C. Radermacher, K. Radtke, D. Rechid, M. Rounsevell, P. Samuelsson, S. Somot, J.-F. Soussana, C. Teichmann, R. Valentini, R. Vautard, B. Weber, P. Yiou. EURO-CORDEX: New high-resolution climate change projections for European impact research, Regional Environmental Change, 14 (2), 563-578, 2014. 